\title{
GENETIC RELATIONSHIP AND POLYMORPHISM OF TURKISH MYRTLES (MYRTUS COMMUNIS L.) AS REVEALED BY INTER SIMPLE SEQUENCE REPEAT (ISSR)
}

\author{
SimSEK, O. $.^{*}-$ DONMEZ, D. $^{2}-$ SARIDAS, M. A. ${ }^{3}-$ PAYDAS-KARGI, S. ${ }^{3}-$ AKA-KACAR, Y. ${ }^{3}$ \\ ${ }^{1}$ Horticulture Department, Agriculture Faculty, Erciyes University, Kayseri, Turkey \\ ${ }^{2}$ Biotechnology Research and Application Center, Çukurova University, Adana, Turkey \\ ${ }^{3}$ Horticulture Department, Agriculture Faculty, Çukurova University, Adana, Turkey \\ *Corresponding author \\ e-mail:ozhan12@gmail.com
}

(Received $30^{\text {th }}$ Jul 2019; accepted $25^{\text {th }}$ Nov 2019)

\begin{abstract}
Myrtle is known native to Southern Europe and North Africa and was naturally grown in tropical and subtropical regions. Myrtle could be grown successfully in soils under hot, arid environments. Myrtle has several genotypes with yellowish-white or bluish-black colored fruits. The present study aimed to investigate genetic diversity among myrtle genotypes with different fruit colors from different parts of Turkey. A total of 28 myrtle genotypes were collected from Adana, Mersin, Hatay provinces of Turkey. 19 ISSR primers were used for the characterization of the 28 myrtle genotypes. In total, 19 ISSR primers produced 99 clear and reproducible DNA band profiles, 89 of which were polymorphic. Therefore, the average polymorphic was $89.90 \%$. In conclusion, we determined that the ISSR molecular markers could differentiate the white and dark-fruited myrtle genotypes. Myrtle genotypes were also separated according to their geographical origin.
\end{abstract}

Keywords: molecular marker, PCR, genetic diversity, plant genetic resources, different fruit-colored

\section{Introduction}

Myrtus communis L., commonly called Myrtle, is one of the significant medicinal and aromatic species (Wannes et al., 2010; Dahmoune et al., 2015). Myrtle is a diploid $(2 \mathrm{n}=2 \mathrm{x}=22)$ plant known to be native to Southern Europe and North Africa (Serce et al., 2008). Myrtle is known to be a member under the Myrtaceae family, which contains 3,000 species were naturally grown in tropical and subtropical regions. Myrtle is largely consumed as spice having several practices in the food, pharmaceutical, and industries (Sumbul et al., 2011; Casaburi et al., 2015). Myrtle plant could also be used as ornamental purposes such as fencing, roadsides, and green cutting (Skekafandeh, 2007; Danial, 2009). Myrtle grows roughly at an altitude of 500-600 m, most particularly in pine forests and riversides in the Taurus Mountains of Turkey (Aydin and Ozcan, 2007). Myrtle is also called as "hambeles," "mersin," or "murt" in Turkish. It can be grown successfully in soils under hot, arid environments. Myrtle has several genotypes with yellowish-white or bluish-black colored fruits (San et al., 2015; Simsek et al., 2017a).

Many different biotechnological methods could be performed to fruit crops to get better ones during plant breeding strategies. One of significant application of biotechnology is known to be molecular markers in fruit science (Donmez et al., 2016). In recent years, it has been observed that biotechnology studies have been adapted to the breeding activities carried out in many plant species together with classical breeding. Especially, it is possible to shorten the breeding process by adapting the molecular 
techniques to the breeding processes and make a selection in terms of some features in the early period by using molecular markers (Simsek et al., 2017b). In recent years, molecular techniques in plant breeding can be beneficial in many ways. Among these molecular techniques, ISSR markers having high usage rates have an important place. Molecular markers overcoming the limitations of morphological and biochemical markers avoid the influence of the environment on the performance of genotypes (Madadi et al., 2017). There are several studies on molecular characterization of myrtle genotypes having different origins in literature by various molecular markers (Bruna et al., 2004, 2007; Messaoud et al., 2007, 2011; Serce et al., 2008; Albaladejo et al., 2009; Melito et al., 2013, 2016, 2017; Nora et al., 2015; Ghafouri et al., 2018; Mele et al., 2019). The present study aimed to investigate genetic diversity among different fruitcolored myrtle genotypes from different parts of Turkey. Especially fruit color was chosen as phenotypic trait besides plant materials were collected from different locations of Turkey to ensure that ISSR markers could discriminate myrtle genotypes.

\section{Materials and methods}

\section{Plant material}

A total of 28 myrtle genotypes were collected from Adana, Mersin, Hatay provinces of Turkey (Table 1). A map with the sampling sites is presented in Figure 1.

\section{DNA extraction}

Total genomic DNA was extracted from leaves tissues by CTAB method (Simsek et al., 2008). The quality and quantity of DNA were detected by NanoDrop (ND 100) spectrophotometer (NanoDrop Technologies, Inc., Wilmington, DE, USA) and agarose gel electrophoresis. DNA samples were subsequently diluted to $10 \mathrm{ng} / \mu \mathrm{l}$ for ISSR-PCR reactions and stored at $-20{ }^{\circ} \mathrm{C}$.

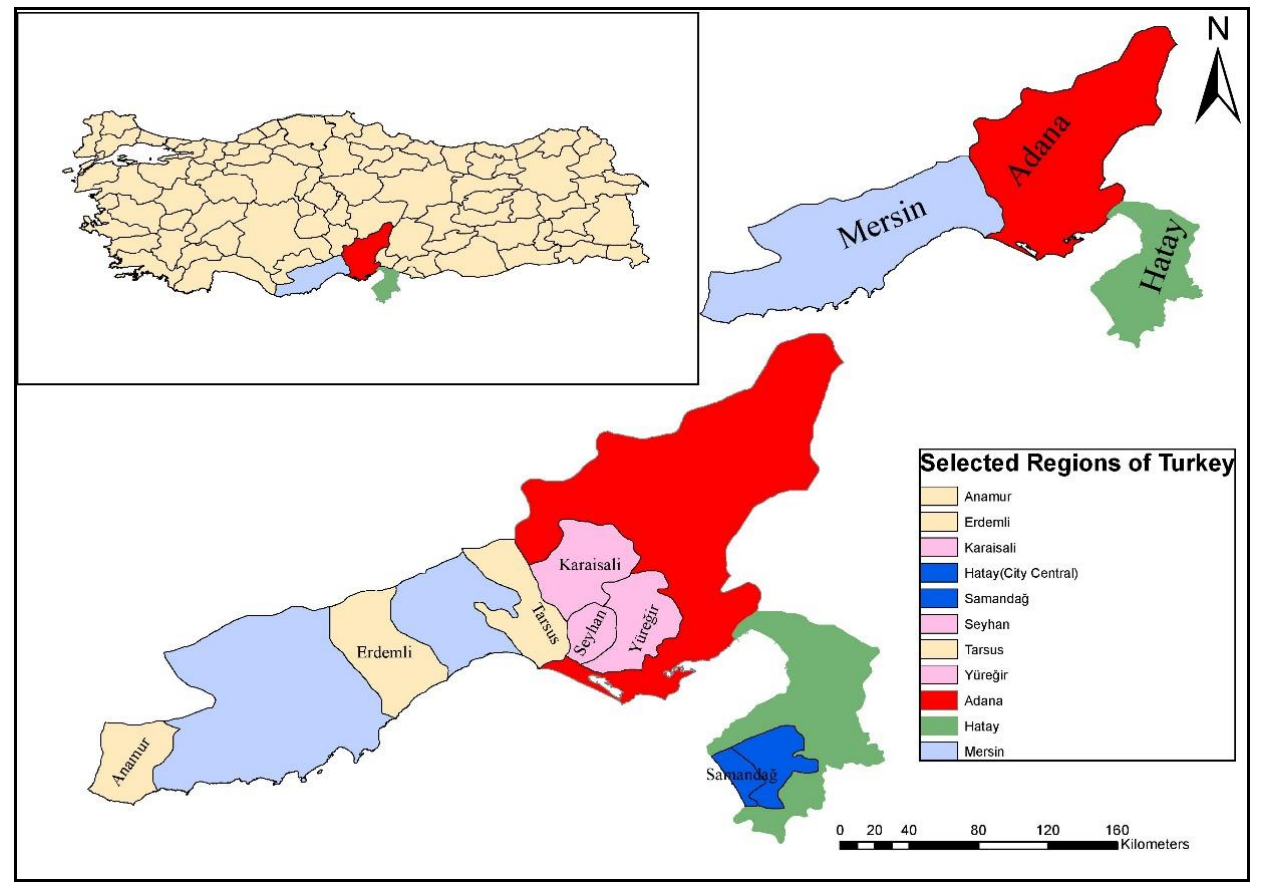

Figure 1. Map with the sampling sites 


$$
-1143 \text { - }
$$

Table 1. Myrtle genotypes and their sampling locations

\begin{tabular}{|c|c|c|}
\hline Name & Sampling location province/city & Fruit color \\
\hline Çelemli1 & Çelemli/Yüreğir/Adana & Dark-fruited \\
\hline Akpınar1 & Akpınar/Yüreğir/Adana & Dark-fruited \\
\hline Akpınar2 & Akpınar/Yüreğir/Adana & Dark-fruited \\
\hline Ziyanlı1 & Ziyanlı/Yüreğir/Adana & Dark-fruited \\
\hline Ziyanl12 & Ziyanlı/Yüreğir/Adana & Dark-fruited \\
\hline Ziyanl13 & Ziyanlı/Yüreğir/Adana & Dark-fruited \\
\hline Seyhan 1 & Çaputçu/Seyhan/Adana & White-fruited \\
\hline Seyhan2 & Mıdık/Seyhan/Adana & White-fruited \\
\hline Tarsus 1 & Kefeli/Tarsus/Mersin & Dark-fruited \\
\hline Seyhan3 & Kayışl1/Seyhan/Adana & White-fruited \\
\hline Erdemli1 & Tömük/Erdemli/Mersin & White-fruited \\
\hline Tarsus2 & Tarsus/Mersin & Dark-fruited \\
\hline Karaisalı & Karaisalı/Adana & Dark-fruited \\
\hline Erdemli2 & Erdemli/Mersin & Dark-fruited \\
\hline Seyhan4 & Gölbaş1/Seyhan/Adana & White-fruited \\
\hline Seyhan5 & Gölbaş1/Seyhan/Adana & White-fruited \\
\hline Seyhan6 & Gölbaş1/Seyhan/Adana & White-fruited \\
\hline Antakya & Antakya/Hatay & White-fruited \\
\hline Samandağ & Samandağ/Hatay & White-fruited \\
\hline Baltacık & Baltacık/Hatay & White-fruited \\
\hline Harbiye1 & Harbiye/Hatay & White-fruited \\
\hline Harbiye2 & Harbiye/Hatay & Dark-fruited \\
\hline Kozan & Kozan/Adana & White-fruited \\
\hline Anamur & Anamur/Mersin & White-fruited \\
\hline Sarıçam 1 & Sarıçam/Adana & White-fruited \\
\hline Sarıçam2 & Sarıçam/Adana & White-fruited \\
\hline
\end{tabular}

\section{ISSR-PCR analysis}

19 ISSR primers were used for characterization of the 28 myrtle genotypes (Table 2). All ISSR-PCR reactions were carried in a reaction containing 2X PCR Mastermix (Fermentas K0171, Waltham, MA, USA), 1 U Taq DNA polymerase (Fermentas EP0402), $25 \mathrm{mM} \mathrm{MgCl} 2,10 \mu \mathrm{M}$ primer, and $10 \mathrm{ng}$ of myrtle DNA. Mixtures were assembled at $0{ }^{\circ} \mathrm{C}$, transferred to a thermal cycler, and then precooled to $4{ }^{\circ} \mathrm{C}$. The amplification was carried out in a model Master Gradient thermal cycler (Eppendorf, Hauppauge, NY, USA) using an optimized in-house program consisting of an initial denaturation step of $3 \mathrm{~min}$ at $95^{\circ} \mathrm{C}$, and then 35 cycles of $45 \mathrm{~s}$ at $94{ }^{\circ} \mathrm{C}, 1 \mathrm{~min}$ at $55^{\circ} \mathrm{C}$, $45 \mathrm{~s}$ at $72{ }^{\circ} \mathrm{C}$, followed by a 7-min elongation step at $72{ }^{\circ} \mathrm{C}$. ISSR-PCR amplification products were separated by agarose gel electrophoresis on $1.5 \%$ agarose gels and $0.5 \mathrm{~g} / \mathrm{mL}$ ethidium bromide in $1 \mathrm{X}$ TAE buffer $(40 \mathrm{mM}$ Tris-acetate, $1 \mathrm{mM}$ EDTA, $\mathrm{pH}$ 8.0 ) for $3.5 \mathrm{~h}$ at $80 \mathrm{~V}$. The fragment patterns were photographed under UV light for further analysis. A 1-kb DNA ladder (Fermentas) was used to determine the fragment size. 
Table 2. ISSR primer list

\begin{tabular}{c|c|c}
\hline No & ISSR primers & DNA sequences (5'-3') \\
\hline 1 & UBC 807 & AGA GAG AGA GAG AGA GT \\
2 & UBC 808 & AGA GAG AGA GAG AGA GC \\
3 & UBC 810 & GAG AGA GAG AGA GAG AT \\
4 & UBC 811 & GAG AGA GAG AGA GAG AC \\
5 & UBC 814 & CTC TCT CTC TCT CTC TA \\
6 & UBC 815 & CTC TCT CTC TCT CTC TG \\
7 & UBC 816 & CAC ACA CAC ACA CAC AT \\
8 & UBC 818 & CAC ACA CAC ACA CAC AG \\
9 & UBC 820 & GTG TGT GTG TGT GTG TC \\
10 & UBC 823 & GTG TGT GTG TGT GTG TC \\
11 & UBC 824 & TCT CTC TCT CTC TCT CG \\
12 & UBC 825 & ACA CAC ACA CAC ACA CT \\
13 & UBC 827 & ACA CAC ACA CAC ACA CG \\
14 & UBC 828 & TGT GTG TGT GTG TGT GA \\
15 & UBC 834 & AGA GAG AGA GAG AGA GT \\
16 & UBC 835 & AGA GAG AGA GAG AGA GC \\
17 & UBC 843 & CTC TCT CTC TCT CTC TA \\
18 & UBC 845 & CTC TCT CTC TCT CTC TG \\
19 & UBC 850 & GTG TGT GTG TGT GTG TC \\
\hline
\end{tabular}

\section{Data analysis}

ISSR data were recorded as 1 for the presence of a band and 0 for its absence to generate a binary matrix. Only reproducible bands were scored for all the accessions tested. All data were analyzed by Principle Coordinate (PCoA) and Cluster analyses using PAST program (Hammer et al., 2001). First, a similarity matrix was generated using Jaccard coefficients. This matrix was then used for PCO. For cluster analyses, the UPGMA (Unweighted Pair Group Method using Arithmetic Average) method was used to construct dendrogram. The bootstrap values for the clusters were calculated by 1000 replicates using PAST program. The representativeness of dendrogram was evaluated by estimating cophenetic correlation for the dendrogram and comparing it with the similarity matrix, using Mantel's matrix correspondence test (Mantel, 1967). The result of this test is a cophenetic correlation coefficient, $r$, indicating how well dendrogram represents similarity data.

\section{Results}

In total, 19 ISSR primers produced 99 clear and reproducible DNA band profiles, 89 of which were polymorphic. Therefore, the average polymorphic was $89.90 \%$. The results of the ISSR analyses for myrtle genotypes are presented in Table 3. The number of alleles determined by each primer ranged from 4 to 7 , with an average of 5.2. In terms of the total number of alleles, UBC811, and UBC824 loci produced the highest number of alleles (7), PIC values ranged between 0.41 (UBC835) and 0.90 (UBC824). 
Table 3. Results of the ISSR analyses for myrtle genotypes

\begin{tabular}{|c|c|c|c|c|c|c|c|}
\hline No & $\begin{array}{c}\text { ISSR } \\
\text { primers }\end{array}$ & $\begin{array}{c}\text { Size (bp) } \\
(\text { min-max) }\end{array}$ & $\begin{array}{c}\text { Number of } \\
\text { alleles }\end{array}$ & $\begin{array}{l}\text { Monomorphic } \\
\text { bands }\end{array}$ & $\begin{array}{c}\text { Polymorphic } \\
\text { bands }\end{array}$ & $\begin{array}{c}\text { Polymorphism rate } \\
\text { (\%) }\end{array}$ & PIC \\
\hline 1 & UBC807 & $630-2000$ & 4 & 0 & 4 & 100 & 0.59 \\
\hline 2 & UBC808 & $750-2200$ & 5 & 1 & 4 & 80 & 0.47 \\
\hline 3 & UBC810 & $600-2000$ & 5 & 0 & 5 & 100 & 0.87 \\
\hline 4 & UBC811 & $250-2200$ & 7 & 0 & 7 & 100 & 0.89 \\
\hline 5 & UBC814 & $740-2000$ & 6 & 1 & 5 & 83.33 & 0.74 \\
\hline 6 & UBC815 & $400-1500$ & 5 & 0 & 5 & 100 & 0.69 \\
\hline 7 & UBC816 & $500-1250$ & 5 & 0 & 5 & 100 & 0.79 \\
\hline 8 & UBC818 & $500-2100$ & 6 & 0 & 6 & 100 & 0.78 \\
\hline 9 & UBC820 & $1100-2000$ & 4 & 1 & 3 & 75 & 0.90 \\
\hline 10 & UBC823 & $1200-2050$ & 4 & 1 & 3 & 75 & 0.75 \\
\hline 11 & UBC824 & $500-2100$ & 7 & 0 & 7 & 100 & 0.90 \\
\hline 12 & UBC825 & $450-1600$ & 5 & 0 & 5 & 100 & 0.95 \\
\hline 13 & UBC827 & $700-1900$ & 4 & 0 & 4 & 100 & 0.66 \\
\hline 14 & UBC828 & $750-1950$ & 6 & 0 & 6 & 100 & 0.87 \\
\hline 15 & UBC834 & $300-1750$ & 6 & 0 & 6 & 100 & 0.76 \\
\hline 16 & UBC835 & $300-2500$ & 6 & 4 & 2 & 33.33 & 0.41 \\
\hline 17 & UBC843 & $750-2150$ & 5 & 1 & 4 & 80 & 0.84 \\
\hline 18 & UBC845 & $500-2150$ & 5 & 0 & 5 & 100 & 0.47 \\
\hline 19 & UBC850 & $1100-1900$ & 4 & 1 & 3 & 75 & 0.70 \\
\hline \multicolumn{2}{|r|}{ Total } & $250-2500$ & 99 & 10 & 89 & $33.33-100.00$ & \\
\hline
\end{tabular}

The dendrogram generated from the UPGMA algorithm based on ISSR data is presented in Figure 2. The validity of the dendrogram in reflecting the genetic relationships among the myrtle genotypes was indicated by a high cophenetic correlation coefficient $(r)$ of 0.88 . Genetic similarity coefficients ranged from 0.37 to 0.97. The UPGMA clustering pattern grouped all the genotypes into two major clusters (Fig. 1). Principle coordinate analysis (PCoA) was also performed using the similarity matrix, and the two-dimensional dendrogram corroborated UPGMA analyses (Fig. 3). While the first axis (Coordinate 1) explained 55.95\% of the total molecular variance, the second axis (Coordinate 2) explained 13.56\%.

Genetic similarities among all myrtle genotypes ranged from 0.37 to 0.97 . The highest similarity rate (1.00) was among Antakya, Samandağ, Baltacik, Harbiye1 genotypes collected from the city of Hatay in southern Turkey, on the eastern Mediterranean coast and they all are white-fruited. The lowest similarity rate was 0.27 , and it was obtained between dark-fruited Akpinar1 collected from Adana and whitefruited Antakya, Samandağ, Baltacık, Harbiye1 collected from Adana.

Based on the similarity index, a clustering dendrogram was constructed using UPGMA. The dendrogram separated all genotypes except Antakya, Samandağ, Baltacik, Harbiye1. The dendrogram grouped all genotypes into two main clusters. The first main cluster included all dark-fruited genotypes except Harbiye2. The second main cluster included all white-fruited genotypes and dark-fruited genotypes (Harbiye2). 


$$
\text { - } 1146 \text { - }
$$

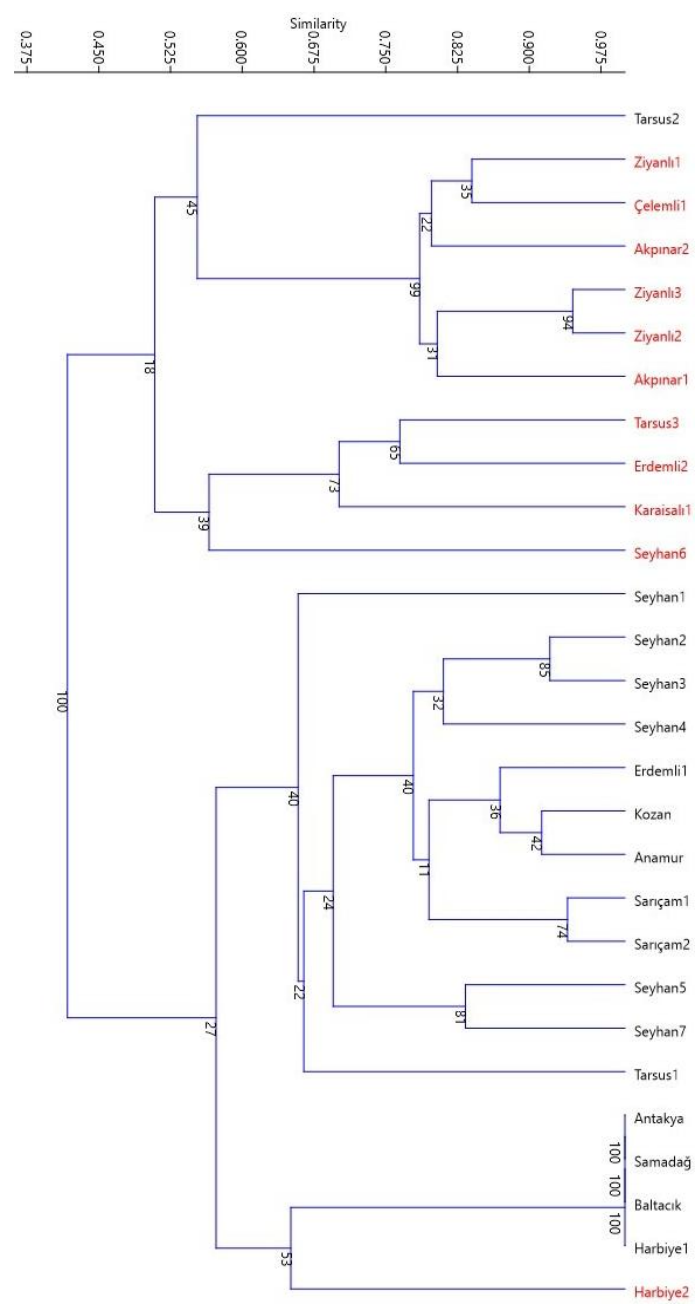

Figure 2. ISSR dendrogram of myrtle genotypes. (Red colors present dark-fruited genotypes, black colors white fruited genotypes)

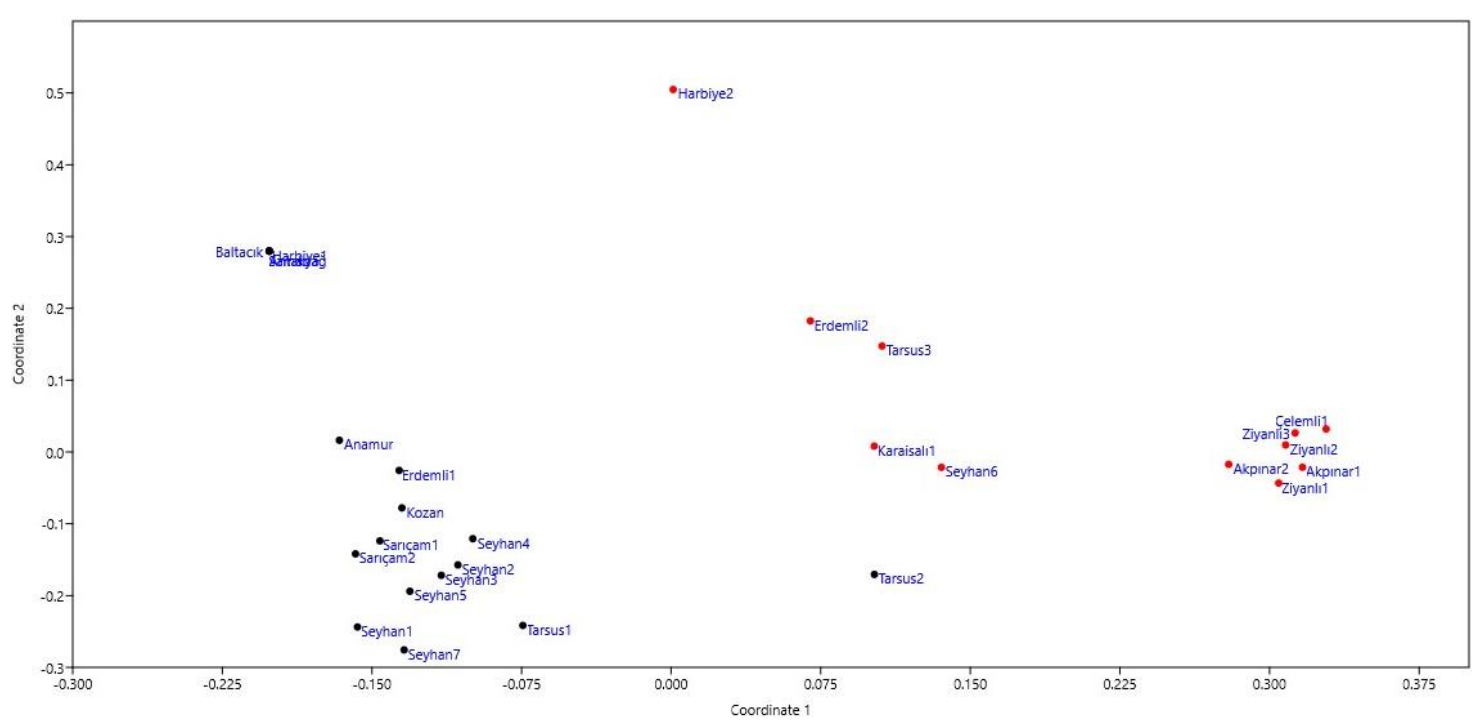

Figure 3. Principle coordinate analysis of 28 myrtle genotypes generated by the data from ISSR analyses. (Red colors present dark-fruited genotypes, black colors white fruited genotypes) 


\section{Discussion}

Plant genetic resources are significant plant materials for breeders. The collection and identification of these plants is the first and important step of plant breeding. The assessment of genetic diversity is a necessary step to protect natural myrtle populations. We examined the genetic diversity among Turkish myrtle genotypes in comparison with fruit color and geography origin. 19 ISSRs produced $89.90 \%$ polymorphism; this result was higher than the results of previous genetic diversity studies (AFLP 56\%: Bruna et al., 2007; RAPD 51.9\%; Messaoud et al., 2007; RAPD 72.9\%: Serce et al., 2008) conducted by different molecular markers.

The evolutionary relationships between the wild and cultivated myrtle types are not well-known. The large-fruited, cultivated type was likely domesticated from the whitecolored, wild types. The fact that all the cultivated myrtle accessions are white-fruited, and the dark-fruited from is prevalent in nature indicates that the white color was preferred during the domestication process (Serce et al., 2008). In our study, we used white and dark-fruited genotypes to estimate evolutionary relationships between white and dark-fruited genotypes. Based on the results, all dark-fruited myrtle genotypes were clustered together except Harbiye2. Harbiye2 is also dark-fruited genotype; however, it is collected different provinces of Turkey. Totally five different genotypes (one of them is dark-fruited) were collected from the city of Hatay. They were clustered together, but the only one dark-fruited genotype Harbiye2 from Hatay was different from the other white-fruited genotypes from Hatay. This result showed that dark-fruited genotypes are certainly different from white-fruited genotypes; however, the differences were also related to geographical origin. Serce et al. (2008) used two sets of myrtle accessions from Hatay, Turkey. Set 1 consisted of two wild accessions, dark- and white-colored forms, and six cultivated selections, while Set 2 contained three open-pollinated individuals from each accession of Set 1 . The researcher examined genotypic variation of Sets 1 and 2 using RAPD markers. According to results, the molecular analysis clearly separated the cultivated types from the wild accessions. In the present study, we used different white and dark-fruited myrtle genotypes from Hatay, Adana and Mersin provinces of Turkey. We confirmed that ISSR analysis separated the cultivated whitefruited types from the wild dark-fruited genotypes. Melito et al. (2013) investigated genetic diversity of 80 wild accessions of Sardinian myrtle collected four different localities (Corsica, Asinara, Surigheddu and Oristano) via ISSR markers. The researchers used totally 17 ISSR primers and among them 12 ISSR primers were informative. Based on the results, there was no convincing evidence of a correlation between genotype and geographical origin. In another study Melito et al. (2016) explored the morphological, chemical, and genetic diversity of wild myrtle populations in Sicily, with the aim to provide a first characterization of a core collection of 36 accessions from 7 localities (Ispica, M. Pellegrino, Misilmeri, R. Zingaro, Scopello, Ribera, Sciacca) for future domestication programs. AFLP fingerprinting generated 152 polymorphic fragments. Structure analysis identified three genetic clusters (cluster A: most of the Misilmeri samples, cluster B: Scopello, Ribera, Sciacca, and M. Pellegrino, cluster C: Ispica and Ribera) corresponding to specific geographical origin. In our study; we used 19 ISSR primers and all ISSR primers proved to be informative. PIC values obtained from ISSR primers were ranged from 0.41-0.90. In the present study, myrtle genotypes collected from different parts of Turkey were used and genotypes were clustered by geographic origin. 


\section{Conclusions}

In conclusion, we determined that the white and dark-fruited myrtle genotypes could be differentiated by the ISSR molecular markers. Myrtle genotypes were separated according to their geographical origin. It is shown that there are significant myrtle genetic resources that are genetically and morphologically different from each other in Turkey.

\section{REFERENCES}

[1] Albaladejo, R. G., Carrillo, L. F., Aparicio, A., Fernández-Manjarrés, J. F., González-Varo, J. P. (2009): Population genetic structure in Myrtus communis L. in a chronically fragmented landscape in the Mediterranean: can gene flow counteract habitat perturbation? - Plant Biology 11(3): 442-453.

[2] Aydin, C., Ozcan, M. M. (2007): Determination of nutritional and physical properties of myrtle (Myrtus communis L.) fruits growing wild in Turkey. - Journal of Food Engineering 79(2): 453-458.

[3] Bruna, S., Mercuri, A., Cervelli, C., Braglia, L., Benedetti, L. D., Schiva, T. (2004): Genetic characterization of Myrtus communis L. populations using AFLP markers [Amplified Fragment Length Polymorphism; Italy]. - Italus Hortus (Italy) 11(4): 332335.

[4] Bruna, S., Portis, E., Cervelli, C., De Benedetti, L., Schiva, T., Mercuri, A. (2007): AFLP-based genetic relationships in the Mediterranean myrtle (Myrtus communis L.). Scientia Horticulturae 113(4): 370-375.

[5] Casaburi, A., Di Martino, V., Ercolini, D., Parente, E., Villani, F. (2015): Antimicrobial activity of Myrtus communis L. water-ethanol extract against meat spoilage strains of Brochothrix thermosphacta and Pseudomonas fragi in vitro and in meat. - Annals of Microbiology 65(2): 841-850.

[6] Dahmoune, F., Nayak, B., Moussi, K., Remini, H., Madani, K. (2015): Optimization of microwave-assisted extraction of polyphenols from Myrtus communis L. leaves. - Food Chemistry 166: 585-595.

[7] Danial, G. H. (2009): Propagation of Myrtus communis L. in vitro. - Journal of Duhok University 12(1): 80-84.

[8] Donmez, D., Simsek, O., Aka Kacar, Y. (2016): Genetic engineering techniques in fruit science. - International Journal of Environmental Research 2(12): 115-128.

[9] Ghafouri, F., Rahimmalek, M. (2018): Genetic structure and variation in different Iranian myrtle (Myrtus communis L.) populations based on morphological, phytochemical and molecular markers. - Industrial Crops and Products 123: 489-499.

[10] Hammer, Ø., Harper, D. A., Ryan, P. D. (2001): PAST: paleontological statistics software package for education and data analysis. - Palaeontologia Electronica 4(1): 9.

[11] Madadi, M., Zamani, Z., Fatahi, R. (2017): Assessment of Genetic Variation within Commercial Iranian Pomegranate (Punica granatum L.) Cultivars, Using ISSR and SSR Markers. - Turkish Journal of Agriculture-Food Science and Technology 5(6): 622-628.

[12] Mantel, N. (1967): The detection of disease clustering and a generalized regression approach. - Cancer Research 27: 209-220.

[13] Mele, C., Corona, L., Melito, S., Raggi, L., Mulas, M. (2019): The genetic diversity of selections and wild populations of myrtle revealed by molecular geographic contexts. Industrial Crops and Products 132: 168-176.

[14] Melito, S., Chessa, I., Erre, P., Podani, J., Mulas, M. (2013): The genetic diversity of Sardinian myrtle (Myrtus communis L.) populations. - Electronic Journal of Biotechnology 16(6): 7-7. 
[15] Melito, S., Dessena, L., Sale, L., Mulas, M. (2017): Genetic diversity and population structure of wild Sardinian myrtle (Myrtus communis L.) genotypes from different microclimatic areas. - Australian Journal of Crop Science 11: 1488-1496.

[16] Melito, S., La Bella, S., Martinelli, F., Cammalleri, I., Tuttolomondo, T., Leto, C., Fadda, A., Molinu, M. G., Mulas, M. (2016): Morphological, chemical, and genetic diversity of wild myrtle (Myrtus communis L.) populations in Sicily. - Turkish Journal of Agriculture and Forestry 40(2): 249-261.

[17] Messaoud, C., Afif, M., Boulila, A., Rejeb, M. N., Boussaid, M. (2007): Genetic variation of Tunisian Myrtus communis L. (Myrtaceae) populations assessed by isozymes and RAPDs. - Annals of Forest Science 64(8): 845-853.

[18] Messaoud, C., Béjaoui, A., Boussaid, M. (2011): Fruit color, chemical and genetic diversity and structure of Myrtus communis L. var. italica Mill. morph populations. Biochemical Systematics and Ecology 39(4-6): 570-580.

[19] Nora, S., Albaladejo, R. G., Aparicio, A. (2015): Genetic variation and structure in the Mediterranean shrubs Myrtus communis and Pistacia lentiscus in different landscape contexts. - Plant Biology 17(2): 311-319.

[20] San, B., Yildirim, A. N., Polat, M., Yildirim, F. (2015): Chemical compositions of myrtle (Myrtus communis L.) genotypes having bluish-black and yellowish-white fruits. Erwerbsobstbau 57(4): 203-210.

[21] Serce, S., Simsek, O., Gunduz, K., Aka-Kacar, Y., Ercisli, S. (2008): Relationships among myrtle accessions from Turkey as revealed by fruit characteristics and RAPD. Roumanian Biotechnology Letters 13(6): 4054-4065.

[22] Shekafandeh, A. (2007): Effect of different growth regulators and source of carbohydrates on in and ex vitro rooting of Iranian Myrtle. - International Journal of Agricultural Research 2: 152-158.

[23] Simsek, O., Kanat, F. E., Serce, S., Kacar, Y. A. (2008): Comparisons of DNA isolation methods for some fruit species. - Derim 25(1): 59-69.

[24] Simsek, O., Bicen, B., Donmez, D., Aka Kacar, Y. (2017a): Effects of different media on micropropagation and rooting of myrtle (Myrtus communis L.) in in vitro conditions. International Journal of Environmental \& Agriculture Research 3(10): 54-59.

[25] Simsek, O., Donmez, D., Aka Kacar, Y. (2017b): RNA-seq analysis in fruit science: A review. - American Journal of Plant Biology 2: 1-7.

[26] Sumbul, S., Ahmad, M. A., Asif, M., Akhtar, M. (2011): Myrtus communis Linn.-A review. - Indian Journal of Natural Products and Resources 395-402.

[27] Wannes, W. A., Mhamdi, B., Sriti, J., Jemia, M. B., Ouchikh, O., Hamdaoui, G., Kchouk, M. E., Marzouk, B. (2010): Antioxidant activities of the essential oils and methanol extracts from myrtle (Myrtus communis var. italica L.) leaf, stem and flower. - Food and Chemical Toxicology 48(5): 1362-1370. 